\title{
A Decade with MALC
}

By H. VAIL DEALE

THE PROLIFERATION of professional groups within the library world has been a long-standing concern of many persons, and the value of many existing units affiliated with state and national associations has frequently been questioned. Yet in the midst of conferences, institutes, and workshops too numerous to mention, one such group, conceived at the grass-roots level, has survived to celebrate its tenth anniversary in the Spring of 1965 . The need for a revitalized academic librarianship in the Midwest was largely responsible for the growth and development of the Midwest Academic Librarians Conference, an informal fellowship of librarians-most of whom share common problems and similar goals.

Conception of the idea behind the now well established Midwest group took place sometime during the closing months of 1953 , though the first historical document appears to be a memorandum dated January 25, 1954, mailed to midwest academic and research librarians by Robert H. Muller, chairman of the College and Research Libraries Section of the Illinois Library Association. Because of a growing sense of dissatisfaction with existing academic librarians' organizations, and perhaps in unconscious emulation of the meetings of eastern college and university librarians held annually at Columbia University, a group of Illinois librarians decided to explore the possibilities in the heart of the Midwest. Dr. Muller's memorandum began: "The open meeting tentatively scheduled for February 4 (1954), at 5:00 P.M. for those interested in organizing annual meetings of midwestern college, university, and re-
Mr. Deale is Director of Libraries in Beloit College, Beloit, Wisconsin.

search librarians has been cancelled."1 In its place, a closed meeting of the Steering Committee of the ILA College and Research Libraries Section was announced, "to which only those will be invited who have expressed an especially strong interest in the proposed annual meetings."2 This January 25th memorandum was mailed to eighty-one librarians of major university, college, and research libraries in nine midwestern states who had earlier received an exploratory questionnaire from the ILA Steering Committee. ${ }^{3}$ A summary of responses to the original exploratory questionnaire indicated that fifty-two out of sixty-nine replies favored the proposed annual meetings; eight replies were conditional; only nine replied in the negative. Institutions which had expressed the strongest objections were five of the large universities in the Midwest. ${ }^{4}$ The most prevalent negative argument was that librarians were already overorganized and there already were too many professional meetings demanding the time, effort, and funds of academic librarians. The affirmative arguments, more enthusiastically voiced, included the need for communication, and the belief that a regional group could be more effective and stimulating than the

\footnotetext{
${ }^{1}$ Memorandum from Illinois Library Association, College and Research Libraries Section, Robert $\mathrm{H}$. Muller, chairman, dated January 25, 1954.

${ }^{2}$ Ibid.

${ }^{3}$ Ibid.

"Iowa State University, Ohio State University, University of Minnesota, University of Wisconsin, and Washington University.
} 
smaller state "sections." Those who had reservations about initiating another professional group indicated they would be interested if such a group held well planned meetings, programed with good speakers, concerned with matters of real substance and providing an opportunity for productive discussion. ${ }^{5}$ Other questions in the exploratory questionnaire had to do with where meetings should be held, their length, etc.

Thirteen librarians gathered for the closed meeting of the ILA Steering Committee at the Morrison Hotel, Chicago, on February 3, 1954. Following a report by Dr. Muller on the results of the exploratory questionnaire, the group discussed the types of program which should be considered if the proposed conference became a reality. There was general opposition to lengthy papers and projects, in favor of provocative papers with opportunities for informal discussion. Also attractive was the possibility of hearing reports on projects, practical in nature, currently being carried on at specific institutions. There followed an informal but significant discussion which brought out many ideas that became part of the basic pattern for all midwest academic librarians' conferences: ${ }^{6}$ (1) meetings should be held on college or university campuses to enable the participants to see how other libraries operate; (2) librarians, other than the chief librarian, should be encouraged to attend so that junior staff members and assistant librarians from small colleges would have a forum for their ideas and an opportunity to get better acquainted. According to the minutes of that meeting prepared by Benjamin B. Richards, secretary pro tem, "too much emphasis cannot be placed on the sense of the committee being in favor of small groups, opportunity for group participation, and the opportunity for comrade-

\footnotetext{
5 Memorandum, op. cit.

- Minutes of the Steering Committee meeting held in the Morrison Hotel, Chicago, February 3, 1954; memorandum dated February 4, 1954.
}

ship among the rank and file. . . ."

On February 5, 1954, a brief closed session was held to discuss next steps as a result of the informal meeting on February 3 . This meeting was attended by Robert B. Downs (University of Illinois), David Jolly (Northwestern University), Martha Biggs (Lake Forest College), and Robert H. Muller (then librarian, Southern Illinois University). It was agreed to hold the first meeting on a Chicago campus, preferably during the week of ALA's Midwinter Meetings, on a day when no ACRL meetings were scheduled. ${ }^{8}$ If the first conference proved successful, subsequent annual meetings might move to other midwestern campuses. It was further decided that this first meeting would be jointly sponsored by the ILA College and Research Libraries Section, the university where the meeting was being held, and the ACRL state representatives, provided they agreed to cooperate in the venture. Suggestions for topics and types of program were to be sent to Dr. Muller, chairman of the ILA College and Research Libraries Section. It was also suggested that a registration fee of one dollar be charged to defray any expense involved in the planning of the conference. This fee has remained the same ever since, though charges for dinners and luncheons have varied from campus to campus. The February 4th minutes significantly included the sentence: "The program will include a tour of the library." 9 This idea later developed into a basic concept: to meet always on a campus with a new, or recently completed, building.

The first conference of midwest academic librarians, which was to have been held in February 1955 in connection with Midwinter ALA, never materialized. Buried in the files or memories of the ILA Steering Committee members, the rea-

T Ibid., p.2.

8 Ibid., p.3.

Ibid. 
sons have never found their way into historical record. According to one member, no Chicago campus volunteered to have the meeting, and it was not until March 1956 that an invitation was issued indicating that a "regional conference devoted to college library problems and open to all librarians in the midwestern states"10 would be held in connection with the opening of the new, four-million-dollar library at Michigan State University, East Lansing, on May 18-19, 1956. This invitation was jointly sponsored by the ILA College and Research Libraries Section and the staff of Michigan State University library, (Jackson Towne, then librarian).

Events of this, the first MALC, were largely related to the "dedication" of the new library building, for it was not until Saturday, May 19, following luncheon, that the group settled down to its own program. Speakers were: Mrs. Patricia B. Knapp (then on the faculty of Rosary College), Mrs. Kathleen B. Stebbins (then on the staff of the Detroit public library), and Cecil K. Byrd (Indiana University libraries). Mrs. Knapp stressed the role which faculty can play in stimulating the use of the academic library; Mrs. Stebbins spoke enthusiastically on recruitment for college librarianship; Mr. Byrd's topic was "Site, Seats, and Selectivity-Some Thoughts on Planning the College Library Building." Of more significance for the present historical sketch was the discussion during the business meeting, where a variety of opinions were expressed concerning the future of the regional conference idea. The ILA Steering Committee had laid the groundwork in its invitation to the East Lansing conference when it said: "If the reception to this first conference is enthusiastic and the attendance satisfactory, a regional meeting could be held every year dealing primarily with the problems of college, university and

${ }^{10}$ Newsletter to midwest librarians dated March 15. 1956, from Steering Committee, Illinois Library Association, College and Research Library Section, Benjamin B. Richards, chairman. research libraries."11 Further "ground rules" had been suggested in the invitation: "Our conference is designed for the participation of the smaller college librarians particularly, and heads of departments, assistant librarians, and junior members in all institutions. It is hoped that the meeting will be friendly and informal as well as scholarly and practical. The committee welcomes all librarians, and if our regional boundaries seem to be exclusive, please disregard state lines and come anyway." ${ }^{2} 2$ The rest is history. ...

Over one hundred visiting librarians from Michigan, Illinois, Indiana, Ohio, Wisconsin, and Kansas travelled to the first MALC and enthusiastically endorsed the idea of continuing the regional conference. Basic principles which have guided the informally structured group since the Spring of 1956 include:

1. The conference is designed primarily for the small college librarian, department heads and assistants from all libraries, and junior members;

2. The conference shall meet on a campus which has a new, or recently completed, library building;

3. The conference usually shall begin at noon on the first day, concluding by the following afternoon (though the timetable is flexible). In some instances, as will be noted, the conference has been jointly sponsored by two institutions within reasonable proximity to one another. The participating states have settled into Michigan, Wisconsin, Illinois, Indiana, Iowa, Minnesota, Missouri, and Ohio.

Benjamin Richards (then librarian, Knox College, Galesburg, Illinois) presided at the first business meeting, called to order at 4:00 P.M. on Saturday, May 19, 1956. After giving a brief summary of activities of the Steering Committee, Mr. Richards distributed the mimeo-

11 Ibid., p.2.

${ }^{12}$ Ibid. 
graphed report on the results of the exploratory questionnaire, and opened the meeting for general discussion. The motion was made that the present Steering Committee continue for an additional year, and the audience gave its approval. Several suggestions were made during the ensuing discussion for the Committee's guidance: (1) That a nominating committee be appointed to present a slate of officers for the 1957 business session; (2) that the committee choose a site for the next annual conference from among the current invitations, "bearing in mind that a small college library could be host during a vacation period"; (3) that the committee make all arrangements for the conference, including publicity, and that they make a greater effort to reach staff members of the larger libraries. After an expression of thanks and appreciation to Jackson Towne, host librarian, and his staff and to the Steering Committee for its efforts, the conference adjourned. Minutes of the meeting were written by Alice J. Appell (then at the University of Illinois), secretary pro tem. Marquette University, Milwaukee, was chosen as the site of the second MALC. ${ }^{13}$ Announcement of the program was made in the March 1957 issue of College and Research Libraries $^{14}$ and the conference convened on Friday and Saturday, May 10-11, 1957. The Miller Brewing Company was host to the visiting librarians at a buffet supper the first evening, and William F. Ready, newly appointed Marquette librarian, was the featured speaker. Others on the program the following day included: Robert B. Downs (University of Illinois), Ralph T. Esterquest (then director, Midwest Inter Library Center) and the academic vice president of Marquette University. Tours of the new Marquette library were a significant part of the two-day program.

In spite of the suggestion made at the

${ }^{13}$ Minutes of the Midwest Academic Librarians Conference business meeting, May 19, 1956.

14 "Second Annual Midwest Academic Librarians Conference," $C R L$, XVIII (March 1957), 146. first conference, the Steering Committee felt that a "formal" organization, with elected officers, was not in keeping with the spirit of the new regional conference. Therefore, following his two-year leadership as chairman, Benjamin Richards tapped his successor, $H$. Vail Deale, the director of libraries, Beloit College. It was also informally agreed that past, and future, "hosts" of the conference would be members of the Steering Committee. Since Celia Hauck, Marquette's able assistant librarian, had been responsible for the hospitality and arrangements in Milwaukee, and since Ferris S. Randall, the assistant director at Southern Illinois University (Carbondale), would be in charge of arrangements for the third conference, Mr. Deale, Miss Hauck and Mr. Randall became the new Steering Committee succeeding the original group headed by Benjamin Richards.

Plans were completed for the third MALC during the fall of 1957 and during the ALA Midwinter Meeting in January 1958. For the meeting on the Southern Illinois University campus, April 25-26, 1958 , in the handsome new library, Ralph McCoy was host librarian, assisted by Ferris Randall and other members of the staff. At a formal dinner, Friday evening, April 25, Francis H. Horn, the former president of Pratt Institute (Brooklyn), was the speaker. Saturday morning's panel discussion on "What is Professional?" was in charge of Robert H. Muller, associate director of the University of Michigan libraries. While attendance at both East Lansing and Milwaukee had been good, the unexpected registration of several hundred librarians at Carbondale seemed to insure the stability and permanence of the "new" regional conference. In addition to the original midwestern states involved, the third conference drew delegates from Kentucky and Missouri. This meeting also confirmed the idea that academic librarians are stimulated by visiting new library buildings, one of the basic features of each of the annual conferences. 
At the conclusion of the business session, following luncheon on Saturday, the chairman was able to announce that the fourth annual conference would be jointly sponsored by two Indiana institutions: DePauw University (Greencastle) and Wabash College (Crawfordsville). Since both had recently completed new buildings, and since they were within twentyfive miles of each other, program planning for the fourth MALC added few problems and many advantages for the Steering Committee in 1959.

Opening on the Wabash campus, Friday, April 24, 1959, the fourth MALC conference began with tours of the Donnelley publishing plant and the new Lilly library. The first general session, followed by "buzz sessions," occupied the afternoon. "Instruction in the Use of the Library" and "The 16th Edition of Dewey vs. Older Editions" were the two topics considered in the small group discussions. Speaker at the conference dinner that evening was Harold Tribolet of R. H. Donnelley \& Sons, Chicago, who delighted his audience with "Meet the Vandals: an Introduction to the Problems of Preserving Valuable Books and Documents." Guests stayed overnight in the numerous motels in the vicinity, and met for "coffee" on the DePauw campus the next morning in the Roy O. West library.

The buzz sessions which continued throughout the morning offered a choice of discussion topics: "Special Services to Be Offered or Avoided" or "Improvement in Staff Communications." A. W. Crandall, chairman of the history department at DePauw, was the luncheon speaker. His topic: "A New Approach to Lincoln." H. Vail Deale, Beloit College, presided at a brief business session which brought the conference to a close. Donald E. Thompson (Wabash) and Russell S. Dozer (DePauw) became new members of the Steering Committee, and Mr. Dozer was named chairman of the conference for the next two years.

A simple but informative brochure an- nounced the fifth MALC early in 1960 , and contained the reminder: "This, the fifth meeting of the conference, will continue the general informality of previous meetings, and is designed to interest academic librarians at all levels [italics mine]. Small groups will discuss mutual problems and programs, with each individual being free to raise questions, to volunteer information, or to propose his own solutions." 15 The conference convened at Grinnell College in Iowa (Henry Alden, librarian), Friday and Saturday, April 2930, 1960.

"Status Seekers or Professionals?" and "Communications between Catalog and Reference Service Functions" were the topics considered in Friday afternoon sessions. Saturday morning sessions considered: "The Undergraduate Library-an Expanding Collection?" and "Communication among Libraries-Too Little, or Too Much?" Howard R. Bowen, president of Grinnell, addressed the group at its dinner Friday evening in the college dining hall. His topic: "Sending Our Dollars to College." At the closing luncheon on Saturday noon, John Carson Rather, specialist for college and university libraries, United States Office of Education, spoke on "The Library Services Branch and Academic Libraries." Visitors had opportunity during the two-day conference to tour the Burling library, designed by Skidmore, Owings and Merrill.

A handsome mail brochure announced the return of the MALC to Michigan for the sixth annual conference in the Spring of $1961 .{ }^{16}$ Katharine M. Stokes, librarian, Western Michigan University, Kalamazoo, was hostess to the group on the weekend of April 14-15, 1961. All meetings were held in the spacious new student center, with registration and coffee between 1:00 3:00 P.M., April 14, in the faculty lounge.

\footnotetext{
15 Mailing folder for the Fifth Annual Midwest Academic Librarians Conference, Grinnell, Iowa, April 29-30, 1960.

${ }^{16}$ Mailing folder for the Sixth Annual Midwest Academic Librarians Conference, Kalamazoo, Michigan, April 14-15, 1961.
} 
The first session was a panel discussion on "Library Cooperation in a Geographical Area," followed by informal discussion groups. Russell S. Dozer, chairman, presided at the formal dinner that evening in the ballroom, introducing speakers and guests seated at the head table. Russell H. Seibert, vice president, western Michigan University, spoke on the "Status and Responsibilities of Academic Librarians" and Robert H. Muller, associate director of libraries, University of Michigan, talked about the "Preparation of Academic Librarians." After tours of the Dwight B. Waldo library Saturday morning, there were sessions on "Freshman Orientation by TV and Teaching Machines" and "Freshman Orientation in the Liberal Arts College." Luncheon speakers were Forrest F. Carhart, Jr., assistant director (now director), Library Technology Project, ALA, and John Carson Rather of the United States Office of Education.

Each year's conference attendance gave continued evidence that such a regional gathering was what midwest librarians wanted, and many of those who came voiced their appreciation in letters to either the host librarian or the chairman of MALC. Additional evidence of the success of the programs were the numerous invitations extended by academic libraries for MALC to meet on their campuses.

The seventh MALC was announced through an elaborate mailing folder that included not only the full program, but also a brief summary of past locations of MALC conferences. ${ }^{17}$ Held in St. Paul, Minnesota, May 11-12, 1962, it was cosponsored by the College of Saint Catherine, the College of Saint Thomas, and Macalester College. The initial invitation read: "We trust you will enjoy the variety of library architecture at our three institutions-at Saint Thomas, a new and traditionally conceived building; at Saint Catherine, a beautiful, new functional li-

${ }^{17}$ Mailing folder for the Seventh Annual Midwest Academic Librarians Conference, St. Paul, Minnesota, May 11-12, 1962. brary; and at Macalester, an unobtrusive but happy solution to an expansion problem." Highlights of this exciting, threeway, conference included a panel Friday afternoon on "Academic Librarians and their Professional Associations," with librarians on the program from Purdue, Kenyon, Quincy College, Lincoln University (Missouri), and Carleton. Informal discussion groups followed the panel presentation.

At dinner on Friday evening, May 11, in Murray hall at the College of Saint Thomas, Reverend Terrence J. Murphy addressed the delegates on the "Legal Aspects of Book Censorship and their Relationships to Academic Libraries." Open house at the College of Saint Catherine library Saturday morning was followed by group discussions on "New Cataloging Rules and their Impact on Readers' Services" and "Circulation Controls and Undergraduate Morality in the Use of Libraries." Following luncheon in Saint Joseph's hall, Katharine M. Stokes, chairman of MALC, presided at the business session and introduced Mark M. Gormley (then ACRL executive secretary) and Frank L. Schick (assistant director, Library Services Branch, United States Office of Education), who spoke briefly about the work of their organizations. James F. Holly (Macalester College) joined the Steering Committee for this conference and succeeded Miss Stokes after the St. Louis MALC the next year.

The academic librarians of the St. Louis area were hosts for the eighth MALC on April 5-6, 1963, when the conference was cosponsored by Washington University and Saint Louis University. ${ }^{18}$ The program focused on building planning, with many and varied new libraries as case studies. The two major libraries were the contemporary John M. Olin library (Washington University), and the Pius XII memorial library (Saint Louis University) completed in 1959 . Opening sessions were held on the Washington Uni-

\footnotetext{
18 "The Eighth Midwest Academic Librarians Con-
} ference," CRL, XXIV (July 1963), 334-36. 
versity campus. Eugene Mackey, of the firm of Murphy and Mackey, designers of Olin library, spoke on "Architects and Librarians," describing the roles of the two professions in planning a library. A panel of librarians discussed Mr. Mackey's talk, followed by group discussions on a wide variety of topics. At dinner in Wohl Center, Dean Joseph Passonneau of the Washington University School of Architecture, spoke on "The Design of a University." Open house at Olin library completed the first day's program.

Tours of the Pius XII memorial library began the program on Saturday, April 6. Two discussion groups held forth between 10:30 A.M. and twelve noon: one on "Centralized Processing for College Libraries" and the other, "College Environment and the College Library." Joseph Reason, librarian at Howard University, on leave that year to be ACRL executive secretary, was the main speaker at luncheon Saturday noon in the Coronado Hotel. "Experiences of an American Librarian in Burma" was the subject of his address. Although invitations from Ohio, Indiana, and Wisconsin were received by the Steering Committee in anticipation of the ninth MALC, Ohio and Wisconsin were eliminated in favor of a double Indiana site. Dates were announced for a 1964 meeting sponsored by the University of Notre Dame and Valparaiso University. Both had new buildings: one representative of large universities and the other an example of small, liberal arts colleges. Victor Schaefer, director of libraries, was host at Notre Dame, and Hermann Grunau, retiring librarian, host at Valparaiso.

The ninth annual MALC met in South Bend on Friday, April 17, 1964, and continued its program on the Valparaiso campus the following day. ${ }^{19}$ Tours of the new nine-million-dollar Notre Dame library were scheduled for the morning, and the first general session held at 2:30 P.M. in the spacious library auditorium. Virginia

\footnotetext{
10 "MALC in Indiana," $C R L, \mathrm{XXV}$ (May 1964), 227-28.
}

Clark, assistant editor for reviewing of ACRL's new CHOICE, moderated a panel on "A Philosophy of Book Selection for Smaller Colleges." Peter Doiron (Oakland University, Rochester, Michigan), Carl H. Sachtleben (St. Louis University), and Donald E. Thompson (Wabash) were the panelists. Frazer Poole, librarian, University of Illinois (Chicago undergraduate division), was the dinner speaker that evening. His topic was: "Automation at the University of Illinois."

Tours of three new campus buildings opened the sessions at Valparaiso: Moellering memorial library, the new Wesemann law library, and the unusually designed memorial chapel which dominates the campus site. A panel discussion on accreditation practices was moderated by James V. Jones, director, St. Louis University libraries. At the noon luncheon in the Union building featured speakers were: Theodore Samore, college and university library specialist, United States Office of Education, and Stephen Ford, librarian, Grand Valley State College, Allendale, Michigan. Mr. Samore spoke on "Academic Library Statistics," while Mr. Ford addressed the group on "Guidelines for Establishing a Liberal Arts College Library," with an added report on "The Naked Patron," the victim of the new Sentronic, the electronic sentry at the Grand Rapids public library. Before the conference adjourned, announcement was made that the tenth anniversary conference of MALC would be held on the Beloit College campus in the Colonel Robert H. Morse library.

Though many details and many names have been omitted from this résumé of the Midwest Academic Librarians Conference, the intention has been to present a brief, historical sketch of a vital professional group. The informality of the organization and its flexibility in spite of certain basic concepts have meant that there are no official records, per se, and not even annual minutes for guidance. Many librarians throughout the seven or 
eight midwestern states have assisted with the planning and arrangements for each of the annual conferences, and the Steering Committee membership has varied from year to year. Those who have had the professional stimulation and shared in the friendly fellowship as participants of these conferences know to whom the credit should go, and that is perhaps the most sensible conclusion for this informal biography of one of the most viable and rewarding professional groups on the American library scene.

\section{ALA Awards, Citations, Scholarships for 1965}

NOMINATIONS ARE INVITED for the several awards which are to be presented by ALA in 1965. Deadline for nominations described below has been set for January 15. Awards for which other deadlines have been established are listed on page 503 .

The Joseph W. Lippincott Award consists of $\$ 1,000$, an engraved medal, and a special citation, and honors outstanding participation in professional library associations, notable professional writing, or other significant activity in the profession. The donor of the award is Joseph W. Lippincott. Five copies of nominations should be sent to Maryan E. Reynolds, chairman, Lippincott Award Jury, Washington State Library, Olympia, Wash.

The Clarence Day Award, $\$ 1,000$, a citation, and a contemporary print suitably engrossed, is made to an individual who has, through substantial work published within five calendar years preceding presentation of the award, promoted love of books and reading. Donor is the reference book section of the American Textbook Publishers Institute. Five copies of nominations should be sent to Mrs. Florinell Morton, chairman, Clarence Day Award Jury, Library School, Louisiana State University, Baton Rouge.

The Melvil Dewey Award, an engraved medal and a citation, is presented to an individual or group for recent creative professional achievment in library management, training, cataloging and classification, or tools and techniques of librarianship. It is donated by Forest Press, Inc. Five copies of nominations should be sent to Dorothy Reeder, chairman, Melvil Dewey Medal Award Jury, Cook Library, State Teachers College, Towson, Md.

The Scarecrow Press Award for Library Literature is a cash award of $\$ 500$ given to an American librarian to recognize outstanding contribution to library literature during the year preceding presentation. Donor is Scarecrow Press. Send nominations to Philip S. Ogilvie, chairman, Scarecrow Press Award Jury, Tulsa City-County Library System, Tulsa, Okla.

The C. S. Hammond Company Library Award of $\$ 500$ and a citation is made to a librarian who has effectively encouraged the use of maps and atlases or promoted an interest in cartography. It is donated by C. S. Hammond Company. Nominations should be made to Helen M. Focke, School of Library Science, Western Reserve University, Cleveland, Ohio, chairman of the award committee.

The Isadore Gilbert Mudge Citation, administered by the Reference Services Division, is given to a person who has made significant contribution to reference librarianship. Nominations should be sent to Edwin B. Coburn, chairman, Isadore Gilbert Mudge Citation Committee, Chief of Indexing Service, H. W. Wilson Company, 950 University Ave., New York 52. 